\title{
Sprawozdanie z Międzynarodowego Forum Współpracy Gospodarczej Polska-Europa- Wschód (Wrocław, 30-31 maja 2019 roku)
}

Dynamika współczesnych przemian gospodarczych coraz mocniej pokazuje, że „środek ciężkości” światowej gospodarki przesuwa się w kierunku szeroko pojętego Wschodu — zarówno tego bliższego, jak i dalszego. Gospodarki państw zachodnich w coraz większym stopniu ustępują miejsca szybko rozwijającym się krajom wschodnim, w szczególności azjatyckim. Wnikliwa obserwacja zachodzących zmian unaocznia konieczność wychodzenia naprzeciw nowym wyzwaniom, które pojawiają się na tle stosunków gospodarczych kształtujących się na osi Polska-Europa-Wschód. Analiza występujących problemów, proponowane rozwiązania i przedstawianie nowych możliwości to cele, które przyświecały organizacji Międzynarodowego Forum Współpracy Gospodarczej Polska-Europa-Wschód, które odbyło się 30 i 31 maja 2019 roku na Wydziale Prawa, Administracji i Ekonomii Uniwersytetu Wrocławskiego. Było ono owocem współpracy Instytutu Nauk Administracyjnych, ze szczególnym uwzględnieniem Zakładu Publicznego Prawa Gospodarczego, oraz Instytutu Rozwoju Biznesu i Przedsiębiorczości.

Motywem przewodnim Forum i jego „międzynarodowości” była współpraca zagraniczna, skupiająca się przede wszystkim na istotnym dla Polski wschodnim kierunku gospodarczym, czyli relacjach gospodarczych łączących Polskę z Rosją. Ważną i doniosłą okolicznością okazała się możliwość goszczenia uczestników Forum z Rosji, reprezentujących Wszechrosyjski Państwowy Uniwersytet Sprawiedliwości. Ich obecność była potwierdzeniem dotychczasowej wieloletniej, udanej współpracy pomiędzy Wydziałem Prawa, Administracji i Ekonomii Uniwersytetu Wrocławskiego a stroną rosyjską. Nie tylko udział delegacji rosyjskiej 
stanowił jednak o „międzynarodowości” Forum — w jego obradach wzięli również udział uczestnicy z Ukrainy, Indii, Chile oraz Botswany.

Uroczyste rozpoczęcie Forum odbyło się w czwartek 30 maja 2019 roku. Forum otworzył prodziekan WPAE dr hab. Jacek Przygodzki, który pogratulował organizatorom podjęcia się organizacji tak istotnego przedsięwzięcia, życzył udanych obrad oraz wyraził zadowolenie, że jest to wydarzenie, które doskonale oddaje ducha współpracy między nauką i biznesem, co wyraża się we współdziałaniu partnera naukowego - Instytutu Nauk Administracyjnych oraz partnera biznesowego - Instytutu Rozwoju Biznesu i Przedsiębiorczości. Następnie wystąpił dr Witold Małecki, który w imieniu INA powitał uczestników, wskazał na wagę tematyki Forum i zarysował główne wątki merytoryczne, poruszane w ramach obrad konferencji. Po nim głos zabrał Dawid Feliszek, który przywitał zebranych w imieniu Instytutu Rozwoju Biznesu i Przedsiębiorczości, wyraził radość z uczestnictwa w konferencji licznie zebranych uczestników z Polski i zagranicy oraz przedstawił plan całego wydarzenia. W końcowej części oficjalnego otwarcia Forum wystąpił Stanisław Gebhardt, prezes Fundacji Odbudowy Demokracji imienia Ignacego Jana Paderewskiego — partnera Forum, który w podniosłych słowach, opierając się na własnym doświadczeniu w działalności społeczno-gospodarczej, podkreślił, jak istotne jest właściwe formowanie stosunków gospodarczych, kształtowanie ich na gruncie wzajemnego szacunku i poszukiwaniu dobra wspólnego.

Pierwszy panel merytoryczny konferencji został poświęcony tematyce formalnoprawnych aspektów transgranicznej współpracy gospodarczej na linii Polska-Europa-Wschód. Należy w tym miejscu nadmienić, że całe Forum prowadzone było w dwóch językach — polskim i angielskim, aby umożliwić efektywny i owocny udział w wydarzeniu wszystkim zagranicznym uczestnikom. W pierwszej części referaty wygłosili: Jekatierina Kowal, która naświetliła problemy tworzenia prawa w kontekście dynamicznie zachodzących przemian gospodarczych; María Gabriela Vásquez Moncayo, której referat dotyczył współpracy gospodarczej w rejonie Azji i Pacyfiku; Wiaczesław Czuchnienko, który zajął się tematem importu towarów w Rosji w świetle aktualnego orzecznictwa; oraz wspólny referat Ewy Kundzicz i Marty Żmudzkiej, które przedstawiły problematykę współpracy między Polską a krajami arabskimi (w szczególności Marokiem i Zjednoczonymi Emiratami Arabskimi), przede wszystkim w zakresie ochrony wzajemnych inwestycji. Wystąpienia przedstawione w ramach panelu opatrzone były odniesieniami do przykładów trwającej współpracy, poruszały ważkie problemy prawno-gospodarcze kształtujące się na jej tle, próbując zidentyfikować ich źródła oraz możliwe rozwiązania de lege ferenda, oraz — co również ważne — spotkały się z ożywionym zainteresowaniem publiczności, która poprzez zadawanie pytań dążyła do dalszego pogłębiania analizowanej tematyki.

Drugi panel merytoryczny swoim wystąpieniem na temat wewnętrznych zwyczajów handlowych w Rosji otworzyła Wiera Pozdiejewa. Kolejny referat wy- 
głosili Oliwia Kuczun i Maciej Marat, którzy skupili się na prawnych i gospodarczych aspektach rozwoju tak zwanego Nowego Jedwabnego Szlaku. Następne wystąpienie przedstawiła Neo Hamaluba, która poddała analizie funkcjonowanie współpracy gospodarczej na linii Chiny-Botswana. Ostatni referat w tej części panelu, a także ostatni pierwszego dnia Forum zaprezentowany został przez Grigorija Komolatowa, który poruszył temat regulacji prawnych odnoszących się do rynków kryptowalut na przykładzie rosyjskich unormowań dotyczących bitcoina.

Kolejny panel merytoryczny drugiego dnia Forum otworzył referat Dawida Feliszka, poświęcony zadaniom państwa w kontekście transgranicznej współpracy gospodarczej. Następnie głos zabrała Karolina Lewicka, która poruszyła temat relacji polityczno-gospodarczych między Polską a Izraelem w kontekście historycznym i współczesnym. Kolejny referat przedstawił Mateusz Lachowski, który omówił zagadnienie konfliktu handlowego pomiędzy Chińską Republiką Ludową a Stanami Zjednoczonymi, podejmując próbę antycypacji skutków tego konfliktu. Następnym prelegentem była Justyna Kukła, której wystąpienie zostało poświęcone wolontariatowi w Polsce i Europie Środkowo-Wschodniej, z uwzględnieniem możliwości jego wpływu na funkcjonowanie współpracy gospodarczej w tym zakresie. Wreszcie ostatnim wystąpieniem w ramach Forum był referat wygłoszony przez Pawła Feliksa, który zajął się problematyką współpracy polsko-rosyjskiej w sektorze energetycznym. Tego dnia, podobnie jak dzień wcześniej, wystąpienia odznaczały się oryginalnością ujęć i wniosków, a ponadto stały się podstawą do burzliwych dyskusji wśród publiczności.

Po wszystkich referatach nastąpiło podsumowanie części merytorycznej Forum. Następnie odbyła się debata na temat obecności młodych ludzi na rynku transgranicznych relacji gospodarczych, którą poprowadziła Katarzyna Wawrzynów z Instytutu Rozwoju Biznesu i Przedsiębiorczości. Wzięli w niej udział: Agnieszka Smółka, chief executive officer w Centrum Nieruchomości „Prosperhome”, Stanisław Gebhardt z Fundacji Odbudowy Demokracji imienia Ignacego Jana Paderewskiego oraz Dawid Feliszek, reprezentujący Instytut Rozwoju Biznesu i Przedsiębiorczości. Uczestnicy debaty podzielili się swoimi doświadczeniami w tym zakresie, omówili obecne wyzwania towarzyszące młodym ludziom rozpoczynającym aktywność zawodową i gospodarczą oraz zachęcili uczestników Forum do odważnego wchodzenia w sferę transgranicznej współpracy gospodarczej na linii Polska-Europa-Wschód.

Organizacja Międzynarodowego Forum Współpracy Gospodarczej PolskaEuropa-Wschód nie byłaby możliwa bez efektywnego współdziałania Instytutu Nauk Administracyjnych Wydziału Prawa, Administracji i Ekonomii Uniwersytetu Wrocławskiego oraz Instytutu Rozwoju Biznesu i Przedsiębiorczości. Istotne zaangażowanie w organizację i przebieg Forum wykazali także partnerzy zewnętrzni — Fundacja Odbudowy Demokracji imienia Ignacego Jana Paderewskiego, Regionalny Ośrodek Debaty Międzynarodowej we Wrocławiu, Zachodnia Izba Gospodarcza Pracodawcy i Przedsiębiorcy oraz Stowarzyszenie Dla Dobra Publicznego. 
Międzynarodowe Forum Współpracy Gospodarczej Polska-Europa-Wschód było ważnym wydarzeniem, które z pewnością warto odnotować w historii wydarzeń organizowanych przez Instytut Nauk Administracyjnych. Poruszyło ono istotny obecnie temat szybkiego rozwoju gospodarczego państw wschodnich, dotykając problemów istotnych w oddziaływaniach gospodarczych między tymi państwami a Polską i Europą. Przyczyniło się także do wzmocnienia współpracy naukowej Uniwersytetu Wrocławskiego z Wszechrosyjskim Państwowym Uniwersytetem Sprawiedliwości oraz innymi ośrodkami zagranicznymi. Warte podkreślenia jest także zwiększenie świadomości uczestników Forum, w tym przedstawicieli podmiotów gospodarczych, w zakresie perspektyw i wyzwań związanych z uczestnictwem w rynkach państw Wschodu. Zainteresowanie problematyką Forum w środowiskach naukowych i biznesowych może sprawić, że stanie się ono przedsięwzięciem cyklicznym, które wpisze się na stałe do kalendarza wydarzeń organizowanych na Wydziale Prawa, Administracji i Ekonomii. Kończąc, pozwolę sobie na podzielenie się osobistą refleksją, w której chcę wyrazić nadzieję, że idea organizacji Forum, którą jest wzmacnianie dobrej i uczciwej współpracy gospodarczej na linii Polska-Europa-Wschód, znajdzie w kolejnych latach kontynuatorów, chcących rozwijać ten projekt i inspirujących się tematyką Forum przynajmniej w takim samym stopniu jak organizatorzy jego pierwszej edycji. 